\title{
un método rápido para determinar la resistencia a los sulfatos de los cementos
} ein schnellprüfverfahren für zemente auf ihr verhalten bei sulfatangriff

A. KOCH y H. STEINEGGER

(«Zement-Kalk-Gipsw, 13, núm. 7, fulio 1960, pág. 317.)

Se describe un método rápido para determinar la resistencia de los cementos a las aguas selenitosas. Este método puede aplicarse a los cementos Portland y a los cementos Portland de alto horno. Se obtienen resultados a los dos meses y medio, aproximadamente. Los cementos que fermanecen intactos después de 56 días de exposición pueden considerarse como resistentes a los sulfatos. Puede hacerse una diferenciación precisa observando la absorción de sulfatos y determinando la resistencia a flexión. Se discute la sensibilidad cle este método rápido y su concordancia en los resultados citando ejemplos. 